IRA-International Journal of Management \& Social Sciences

ISSN 2455-2267; Vol.07, Issue 01 (2017)

Pg. no. 84-95

Institute of Research Advances

http://research-advances.org/index.php/RAJMSS

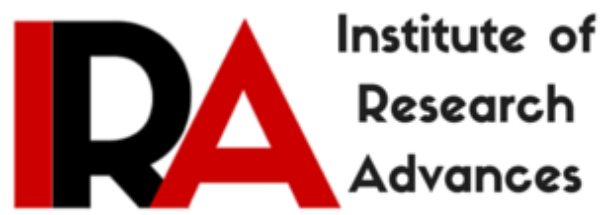

\title{
Determinants of Profitability and Firm Value: Evidence from Indonesian Banks
}

\author{
Sutardjo Tui ${ }^{1}$, Mahfud Nurnajamuddin ${ }^{2}$, Mukhlis Sufri ${ }^{3}$, Andi Nirwana ${ }^{4}$ \\ ${ }^{1}$ Doctoral Student in Faculty of Economics, Muslim University of Indonesia, Indonesia. \\ ${ }^{2,3,4}$ Faculty of Economics, Muslim University of Indonesia, Indonesia .
}

Type of Review: Peer Reviewed.

DOI: http://dx.doi.org/10.21013/jmss.v7.n1.p10

\section{How to cite this paper:}

Tui, S., Nurnajamuddin, M., Sufri, M., \& Nirwana, A. (2017). Determinants of Profitability and Firm Value: Evidence from Indonesian Banks. IRA-International Journal of Management \& Social Sciences (ISSN 2455-2267), 7(1), 84-95. doi:http://dx.doi.org/10.21013/jmss.v7.n1.p10

(C) Institute of Research Advances

(cc) EY-NC

This work is licensed under a Creative Commons Attribution-Non Commercial 4.0 International License subject to proper citation to the publication source of the work.

Disclaimer: The scholarly papers as reviewed and published by the Institute of Research Advances (IRA) are the views and opinions of their respective authors and are not the views or opinions of the IRA. The IRA disclaims of any harm or loss caused due to the published content to any party. 


\begin{abstract}
This study aims to analyze the effect of intellectual capital, firm size and bank liquidity on profitability and firm value. The experiment was conducted in the banking industry listed in Indonesia stock exchange from 2013 to 2015 as many as 40 banks. Data were analyzed using of Analysis of Moment Structures Ver.22. The results showed (1) intellectual capital has a positive and significant effect on the firm profitability and firm value; (2) firm size have a positive and insignificant effect on the firm profitability and firm value; (3) liquidity has a positive and significant effect on firm profitability, but liquidity have a negative not significant effect on the firm value; and (4) the firm profitability has a positive and significant effect on firm value.
\end{abstract}

Keywords: intellectual capital, firm size, liquidity, profitability, firm value

\title{
Introduction
}

Globalization and technological innovation and tight business competition at the moment is also forcing companies to change the way they do business. So that companies continue to survive, companies must quickly change its strategy from a business based on labor-based Business towards $a$ business based on knowledge, so that the main characteristics of the company into a knowledge-based company. With the changing economy characterized by knowledge-based economy with the implementation of knowledge management, the progress of a company will depend on a transformation of creation and capitalization of knowledge itself (Sawarjuwono, 2003; 36). Intellectual capital is a source of intangible value creation associated with the ability of employees, organizational resources, and the operating system as well as relationships with stakeholders important in creating sustainable competitive advantages (Chen et al., 2005).

The theory of intellectual capital was first born from the idea Theodore William Schultz (1961: 1), and then developed by Gary Stanley Becker (1962: 9) that invest in training and to improve the human capital is important as an investment than other forms of capital. Skill, experience, and knowledge have economic value to the organization because it allows for a productive and adaptable.

The previous study that examined the association between the components of intellectual capital and financial performance and firm value indicates that the components of intellectual capital is positive and significant effect on the financial performance and firm value (Fier \& Williams, 2003; Ming Chin et al.,2005; Farah \& Arief, 2006; Tan et al.,2007; Daniel Ze'ghal \& Anis Maaloul, 2010; Olayinka \& Uwalomwa, 2011; Reza Gharoie Ahngar, 2011; Abbasali Daryaee et al.,2011; Mu Shun Wang, 2011; Nova Lili \& Didik Ardiyanto 2012; Meri Fenm Wu et al., 2012; Laila Asadi, 2012; Wasim et al.,2012; Nora \& Siddiq, 2012; Omid Amri \& Mohamadreza Abdoli, 2012; Seyed Alireza Mosavi et al., 2012; Budiadriani, 2014 ).

Companies in Indonesia will be able to compete when using the competitive advantage gained through creative innovations produced by the company's intellectual capital. This will encourage the creation of products that are more favorable in the eyes of consumers. Intellectual capital has become a very valuable asset in the modern business world (Abidin, 2000: 46). The banking company in Indonesia either go public or that has not gone public yet that incorporate intellectual capital into the financial statements of the company, the fact that the reason for the importance of this research.

The growth rate of profit the company can be seen in the form of increased profitability, as well as measure and determine the financial performance of companies running operations, such as the return on assets (ROA), return on equity (ROE), and Nett interest margin (NIM), if the profitability achieved by the company means higher stock returns higher result, for it can be shown in following the table: 
Table 1.

The growth of ROA, ROE and NIM of the banking industry in Indonesia

\begin{tabular}{|l|l|l|l|}
\hline Years & $\begin{array}{l}\text { Return on Asset } \\
(\%)\end{array}$ & $\begin{array}{l}\text { Return on Equity } \\
(\%)\end{array}$ & Nett Interest Margin (\%) \\
\hline 2013 & 1,68 & 7,87 & 5,78 \\
\hline 2014 & 1,42 & 9,87 & 5,30 \\
\hline 2015 & 1,00 & 5,82 & 5,06 \\
\hline average & 1,37 & 7,85 & 5,38 \\
\hline
\end{tabular}

Source: Indonesia Stock Exchange (2016)

Based on the above data can be explained that the development of the banking industry ROA in Indonesia decreased, while the ROE significant fluctuations, as well as banking Nett interest margin continued to decline. Inconsistency findings of previous studies, provide evidence that, that BOPO positive and significant effect on ROA (Kesowo, Kuncoro \& Suharjono, 2002), whereas other studies, shows that the ratio of operating expenses to operating income (ROA) negative and significantly effect on ROA (Yuliani 2007; Rinawan, 2009).

Past studies that analyze the size of the company also showed no difference in the result, that a significant difference between the size of the company to profitability partially, that the greater the size of the company's value can explain and predict the increase in profitability. Conversely the lower the value of the size of the company can explain and predict the decline of profitability, that the bigger the company followed with increasing profitability (Moh.Rifai, Rina Arifati \& Maria Magdalena, 2014), the results obtained denial that firm size does not significantly effect on the banking profitability (AA. Yogi Prasanjaya \& I Wayan Ramantha, 2013: 230-245).

\section{Literature review and hypothesis development Intellectual Capital}

Intellectual capital is expressed as an intellectual matter of knowledge, information, intellectual property, which is used to create the experience of welfare (Stewart, 1997). Another view defines intellectual capital as a process management specialized technology to calculate the company's prospects in the future (Mouritsen, 1998). Intangible assets category is something related to technology, consumer, contract, data processing, personal capital, marketing, location, and goodwill. This definition is broad and includes almost all dimensions of intangible assets (Reilly, 1992). To achieve the company's success greatly influenced by the efforts of the company routine to maximize the values of the company's intellectual capital. Intellectual capital will give the value of diversity. Values of different organizations such as the increase in profits from the acquisition of another company innovation, consumer loyalty, cost reduction and productivity improvement (Edvinsson \& Sullivan, 1997).

Empirical evidence shows that intellectual capital is positive and significant effect on the financial performance (Mu Shun Wang, 2011). Analysis of intellectual capital in the banking company to provide proof that intellectual capital is positive and significant impact on financial performance in the banking sector in Pakistan (Wasimul Rehman, Hafeez Ur Rehman, Muhammad Usman \& Nabila Asghar, 2012; Nora Riyanti Ningrum \& Shiddig Nur Rahardjo 2012). Differences in the results showed that the value added intellectual coefficient (VAIC) effect a negative and no significant effect on the market value, capital employed efficiency (CEE) has a positive and no significant effect on the market value, human capital efficiency (HCE) is a positive and significant effect on the firm value, efficiency of structural capitally (SCE) and no significant negative effect on the market value. VAIC Furthermore, CEE, HCE 
and SCE respectively positive and significant impact on financial performance (ROE, ROA, and Growth Revenue) (Seyed Alireza Mosavi, Shekoufeh Nekoueizadeh \& Mahnoosh Ghaedi, 2012).

The findings of other researchers suggest that the intellectual capital (VAIC) has a positive effect on the market value and financial performance proxy by ROE, ROA, and VACA, and STVA positive effect on market value and financial performance proxy by ROE and ROA, while VAHU no effect the market value and financial performance proxy by the ROA (Nova Lili Entika \& Didik Ardiyanto, 2012). Similar results have proven that the intellectual capital positive and significant impact on the financial performance of companies (Mei Fen Wu, Yu Je Lee \& Goa Liang Wang, 2012; Leila Asadi, 2012).

Then other evidence inconsistent showed that the capital component of intellectual consisting of value added capital employed, and value added structural capital respectively positive and significant impact on the financial performance and corporate value, while the value added human capital has a positive effect and no significant effect on the financial performance and the firm value (Budiandriani, 2013). Intellectual capital is a positive and significant effect on the financial performance (Fier, S \& Williams, SM, 2003). Intellectual capital (VAIC) positive effect on the market value and financial performance (Ming Chin Chen, Shu Ju Cheng \& Yuhchang Hwang, 2005). Similar results have shown that the IC has a positive effect on financial performance (Tan, HP, D Plowman \& P Hancock, 2007; Daniel Ze'ghal \& Anis Maaloul, 2010; Budi Artinah 2011; Olayinka Olamide Marte Uadiale \& Temitope Fagbemi, 2011; Reza Gharoie Ahangar, 2011). Based on this evidence, and then formulated the hypothesis, as follows:

$\mathrm{H}_{1} \quad$ Intellectual capital has a positive and significant effect on firm profitability

\section{Firm size}

Firm size is a proxy of the volatility of operational and inventory controllability supposed economies of scale size of the company demonstrated achievement of current operations and inventory control. The size of the company is the average net sales for the year to several years. In this case the sale is greater than the variable costs and fixed costs, it will obtain the amount of income before taxes. Conversely, if the sale is smaller than the variable costs and fixed costs, the company will suffer a loss (Bringham \& Houston 2001). The size of the company described the size of a company showing by total assets, total sales, average total sales and average total assets, thus the size of the company is the size or magnitude of the assets owned by the company (Ferry \& Jones, 2001).

Past studies that analyze the effect of firm size on the business risk the company found that the size of the risks affecting the business, that small firms have the risk and returns higher than large companies (Miswanto and Husnan, 1999). Similar results have proved that the size of the company and significant positive effect on firm value (Leila Asadi, 2012). Company size is partially positive and significant impact on the value of the company, the larger the size of the company from a company it also increase the value of the company, and Leverage partially significant positive effect on Company Value (Gusti Bagus Angga Pratama and I Gusti Bagus Wiksuana, 2016). There is positive and significant correlation between the sizes of the company to profitability (Moh. Rifai, Rina Arifati \& Maria Magdalena, 2014). Firm size has a positive and significant effect on the bank's performance as measured by ROA (Asma 'a Al-Amarneh, 2012; Abdul Rasyid, 2015).

$\mathrm{H}_{2}$ : Firm size has a positive and significant effect on firm profitability

\section{Liquidity}

The concept of liquidity can be interpreted as the company's ability to pay off a number of short-term debt, generally less than one year (Harmono 2014: 106), mentioned that the dimensions of the concept of liquidity include current ratio, quick ratio, cash ratio, and net working capital to total assets ratio. The dimensions of the concept of liquidity reflects management performance measures in terms of the extent 
to which the management is able to manage working capital, funded from current debt and cash balances of the company.

Determining the level of liquidity of the company's liquidity ratio used consisted of (1) current ratio, (2) quick ratio, (3) absolute liquidity ratio (Harmono, 2014: 118). The main cause of the incident shortage and the company's inability to pay such obligations are a result of negligence management in the operations, then other causes are prior to the company's management does not calculate financial ratios are given so as not to know that the actual condition of the company is already in a state of no longer because the value debt higher than its current assets, if the company has been analyzing the ratio associated with it, companies can find out easily the actual conditions and the company's position, then the company can try to find a way out. Financial analysis related to the company's ability to pay debts or obligations known as liquidity ratio analysis.

Empirical facts prove that the bank capital adequacy ratio (CAR), ROA, loan to deposit ratio (LDR) and firm size have a significant effect on the bank profitability, while the CAR had no significant effect on the profitability of banks who peddle copies of its shares on Indonesia Stock Exchange (Yogi Prasanjaya \& I Wayan Ramantha, 2013). Third party funds, ROA, capital adequacy ratio (CAR), and loan to deposit ratio (LDR), is significant effect on the bank's performance (ROA) (Bambang Sudiyatno, 2010).

$\mathrm{H}_{3} \quad$ Liquidity has a positive and significant effect on firm profitability

\section{Profitability}

The concept of profitability is often used as an indicator of the company's fundamental performance represents performance management (Harmono 2014: 110), according to research developments in financial management, profitability dimensions generally have a causal relationship to the value of the company. While the value of the company as a concept can be explained by the value determined by the price of the stock traded capital markets. Causality shows the dimensions of profitability and good condition, it will have a positive impact on the decisions of investors in the capital market; the case will also affect the creditor's decision in relation to the company through debt financing. In concept it can be concluded that the company's fundamental performance proxy by the dimension of the company's profitability has a causal relationship to the value of the company through stock price indicators and capital structure of the company with respect to the amount of the composition of the company's debts. Profitability also is the end result of a number of policies and decisions of the management company (Brigham \& Houston, 2009: 95). Companies that have a high level of profitability each year, have a tendency to use their own capital as compared with using debt (Kusuma, 2011), another assumption states with return on a high assets, which means that the net profit of the company is high.

Profitability ratio is the ratio to assess the company's ability to make a profit (Kashmir, 2012: 196); this ratio also provides a measure of the effectiveness of management of a company. It is intended by the profits generated from sales and investment income, the point is the use of this ratio indicates the efficiency of the company. The empirical evidence shows that profitability has a positive and significant effect on the firm value (Nova Lili Entika \& Didik Ardiyanto, 2012; Budiandriani, 2013; Shinta Manurung D. et al., 2014; Abd. Rasyid, 2015). While other studies indicate that the value added intellectual coefficient (VAIC), capital employee efficiency (VACA), human capital efficiency (VAHU) positive and significant impact on financial performance and structural capital efficiency (STVA) positive and significant impact on the financial performance (Farah Margaretha and Arief Rakhman, 2006).

$\mathrm{H}_{4} \quad$ Profitability has a positive and significant effect on firm value 


\section{Firm value}

Firm value is very important because of the high value of the company which will be followed by a high prosperity shareholder (Bringham \& Gapenski, 1996: 91), the higher the stock price, the higher the value of the company. Common firm value indicated by the price to book value. Price to book value high above will make the market believe the company's prospects in the future. The ratio of stock price to book value or price-book value (PBV) indicates the level of the company's ability to create value relative to the amount of capital invested. The high PBV is reflects the stock price than the book value per share. The higher the stock price, the more successful the company to create value for shareholders. The company's success is certainly create value gives hope to the shareholders in the form of greater profit anyway (Sartono, 2001: 37). The company's value can be measured by the share price in the market, based on the formation of the company's stock price in the market, which is a reflection of the public's vote by the company's performance in real terms (Harmono, 2014).

The ratio used in assessing the ratio of enterprise value is price earning ratio (PER) is the ratio between the market price per to earnings per share and earnings per share is a form of granting benefits granted to the shareholders of each share of stock owned (Fahmi Irham, 2013). The empirical evidence shows that the intellectual capital or value added intellectual coefficient (VAIC), capital employee efficiency (VACA) and capital efficiency (STVA) and human capital efficiency (VAHU) have a negative and insignificant effect on firm value (Farah Margaretha \& Arief Rakhman, 2006).

$\mathrm{H}_{5 \mathrm{a}} \quad$ Intellectual capital has a positive and significant effect on firm value

$\mathrm{H}_{5 \mathrm{~b}} \quad$ :Firm size has a positive and significant effect on firm value

$\mathrm{H}_{5 \mathrm{c}} \quad$ Bank liquidity has a positive and significant effect on firm value

\section{Methods}

The study using an explanatory research approach. This study will be conducted at a financial services company listed on the Indonesia Stock Exchange (BEI), the sample in this research is the overall banking industry listed in Indonesia Stock Exchange as many as 40 banks during the period 2013 - 2015. Data analysis was performed using a test Analysis of Moment Structures Ver.22.

\section{Results}

Goodness of Fit Model

Table 2 Goodness of Fit Indices Overall Model

\begin{tabular}{|l|l|l|l|}
\hline Goodness of fit index & Cut-off Value & Suitability Index Model & Description \\
\hline Chi-square & small Expected & 88659 & Marginal \\
\hline Probability & $\geq 00: 05$ & 0,015 & Marginal \\
\hline CMIN / DF & $\leq 2: 00$ & 1.430 & Good \\
\hline RMSEA & $\leq 0.08$ & 0.060 & Good \\
\hline GFI & $\geq 0.90$ & 0.916 & Good \\
\hline AGFI & $\geq 0.90$ & 0.837 & Marginal \\
\hline TLI & $\geq 0.95$ & 0.969 & Good \\
\hline CFI & $\geq 0.95$ & 0.982 & Good \\
\hline
\end{tabular}

Source: Hair (1992), Arbuckle (1997)

The evaluation of the model showed of the eight criteria of goodness of fit indices there were five who meet the criteria while AGFI already approaching a critical value, so it can be concluded that the overall model can be said to have been in accordance with the data and can be analyzed further. 


\section{Effect of Intellectual Capital on Profitability}

Intellectual capital has a positive and significant effect on profitability, can be proved by the path coefficient of 0,282 and p-value of $0.015<0.05$. These results explain that the intellectual capital has a positive and significant effect on profitability so that $\mathbf{H}_{\mathbf{1}}$ filed proven to be accepted or supported by empirical facts.

This finding is consistent with results of studies that prove that the Intellectual Capital has a positive influence on the financial performance of the company, is not only a positive effect on the company's performance for the year, even intellectual capital can also predict future financial performance. Intellectual capital is the most appropriate predictors of financial performance (Fier \& Williams, 2003; Chen et al., 2005; Tan et al., 2007).

It's can be explains that the indicators used in this study, namely Vace, VAHC and VASC is the embodiment of the funds expended for the overall knowledge and education in the company, in addition to the existing knowledge on human capital, which includes data-based, organizational charts, manual process, strategies, routines and something that is higher than the value of the materials at least been able to create added value for the company, so it can be concluded that the intellectual capital to provide added value on top of the added value for the company, thus the intellectual capital is needed for development of the company, including a consideration in predicting the development of the company in the future.

\section{Firm size effect on the profitability}

The firm size have a positive and no significant effect on banks profitability, can be proved by the path coefficient of 0.104 and $p$-value of $0,438>0,05$, these results explain that the firm size have a positive no significant effect on banks profitability, so that $\mathbf{H}_{2}$ proposed is not proved or supported by empirical facts.

It's can be explained that the firm size has no significant effect on the ability of the company makes a profit or profitability, because the profitability of the company was assessed by the percentage while the firm size using a number or nominal value such as the number of sales, amount of assets and total capital of all using the nominal rate so that profitability is not significantly affected by the size of the company but strongly influenced by the efficiency of the company. The profit corporation occurs if the sale is greater than the variable costs and fixed costs, otherwise if the sale is smaller than the variable costs and fixed costs, the company will incur a loss (Bringham \& Houston, 2001).

This study rejected the findings provide evidence that the company has a small scale tend to be less profitable than large-scale enterprise (Panjaitan et al., 2004: 42). The firm size affects business risk (Miswanto \& Husnan, 1999). Large companies will be easier to enter the capital market so as to have this opportunity companies pay large dividends to shareholders means great profitability levels (Weston \& Copeland, 2010: 100).

\section{Liquidity effect on profitability.}

Liquidity is a positive and significant effect on the profitability, can be proved by the path coefficient of 0.592 and p-value of $0,002<0,05$. This result explains that the liquidity is positive and significant impact on profitability, so that $\mathbf{H}_{3}$ proposed proved to be accepted or supported by empirical facts.

The findings of the study explained that the liquidity consisting of current assets and current liabilities the company's working capital used for the company's activities so that the company can make a profit, and therefore liquidity and significant positive effect on the profitability of the company. These findings coincide with the findings provide evidence that the dimensions of the concept of liquidity reflects management performance measures in terms of the extent to which the management is able to manage working capital, funded from current liabilities and cash balances of the company. Performance 
management company the profit is meant is measured by the profitability of the company (Harmono, $2014 ; 106)$.

\section{Profitability effect on firm value.}

Profitability is significantly effect on firm value, can be proved by the path coefficient of 0,342 and the pvalue of $0,000<0,05$. This result explains that profitability has a positive and significant effect on firm value, so that $\mathbf{H}_{\mathbf{4}}$ filed proved to be accepted or supported by empirical facts.

The theory underlying the relationship between profitability and value of the company explained that the financial statements and the disclosure of important and meaningful to management as a means of communicating governance and company performance to stakeholders, a high profitability reflects the company's ability to generate high returns for shareholders (Weston and Copeland 2010; in Abdul Rasyid, 2015: 171).

The results of this study support the findings of previous investigators, that profitability and significant positive effect on firm value. This means that the high profitability of the company can show better prospects to investors so that investors will be interested in companies that have a high profitability (AA. Ngurah Putra Adi Dharma \& Putu Vivi Lestari, 2015).

\section{Effect of intellectual capital on firm value}

Intellectual capital is positive and significant effect on firm value of the company, can be proved by the path coefficient of 0,293 and the p-value of $0,000<0,05$. The results stated that intellectual capital is positive and significant impact on firm value, so that $\mathbf{H}_{5 \mathbf{a}}$ proposed proved to be accepted or supported by empirical facts.

The findings of this study explains that intellectual capital consists of value added capital employed (VACE), value added human capital (VAHC), and value added structure of capital (VASC) produces components calculation of output and input, output consists of the total amount of credit granted and other income, inputs consist of interest expense of third party funds and other charges in addition to employee expenses, capital employed is total capital and net profit after tax as well as human capital (HC) is total salaries and wages, including incentives for employees.

Overall these components above the influence the profitability of the company, if the company's profit increased then an improvement in earnings per share (EPS), the price earnings ratio and price to book value which is a measure of the value of the company. This study supports the evidence that capital intellectual positive effect on the market value and financial performance (Chen et al., 2005).

\section{The effect of firm size on firm value.}

The firm size is a positive and significant effect on firm value, can be proved by the path coefficient value of 0,655 and the $p$-value of $0,000<0.05$. The results stated that the firm size has a positive and significant effect on firm value, so that $\mathbf{H}_{\mathbf{5 b}}$ filed proven to be accepted or supported by empirical facts

Firm size seen from the total assets owned by the company can be used for the activities of the company, if the company had assets that great then the company can freely use existing assets in the company, a large company would easily access the capital requirements on the capital market, with the ease that it means that the company has easy access to capital and this capital can be operated on the activities of the company, which thereby generating higher earnings. The results support the findings of previous investigators, that profitability has a positive and significant effect on firm value (Shinta D. Manurung, 2014 Abd. Rashid, 2015). 


\section{Liquidity effect on firm value.}

Liquidity is significant effect on firm value, can be proved by the path coefficient value of -0.294 and the p-value of $0,053>0.05$. This result explains that liquidity is negative and not significant effect on firm value, so that $\mathbf{H}_{\mathbf{5 c}}$ proposed is not acceptable or is not supported by empirical facts.

Current assets of companies the higher the resulting number of bank funds idle (not supplied in the activity in the form of loans that generate interest), which in turn affects the reduction in the bank to earn a profit, and if the bank profit decreases, the prosperity of shareholders decreased.

The results support the findings of previous investigators that liquidity is negative and not significant on firm value (Ni Kadek Ayu Sudiani \& Ni Putu Ayu Darmayanti, 2015), then reject findings explaining that liquidity is positive and significant effect on firm value (AA. Ngurah Dharma Adi Putra \& Putu Vivi Lestari, 2015).

\section{Conclusions and Recommendations}

Intellectual Capital consisting of value added capital employed and value added value added human capital and structural capital and significant positive effect on the profitability and value of the company in the banking industry listed in Indonesia Stock Exchange. Company size which consists of total sales, total assets and total capital is positive but not significant effect on profitability, but positive and significant impact on the value of the company in the banking industry listed in Indonesia Stock Exchange. Liquidity consists of capital adequacy ratio, loan to deposit ratio and loan non-performance positive and significant impact on profitability and as well as no significant negative effect on firm value in the banking industry listed in Indonesia Stock Exchange. Profitability which consists of return to assets, return to equity, Nett interest margin, positive and significant impact on the value of the company in the banking industry company listed on the Indonesia Stock Exchange.

Intellectual capitals efficient having a positive impact and has strong competitiveness to encourage developing company continue to occur, so that for companies leveraging intellectual capital they have and ultimately increase profitability and corporate value. Improving investor confidence by presenting financial statements that continuously by taking into account the intangible value that comes from intellectual capital. Utilizing the company's size as much as possible to improve the profitability of banks, this in turn can boost shareholders through dividend payments.

\section{References}

1. Abbasali Daryaee, Abdolah Pakdel, Kamal Easapour, and Malek Mohamadi Khalaflu (2011). Intellectual Capital, Corporate Value and Corporate Governance (Evidence From Tehran Stock Exchange), Australian Journal of Basic and applied Sciences, 5(12),2011,821-826.

2. Abdol Mohammadi, M.J. (2005). Intellectual capital disclosure and market capitalization, Journal of Intellectual Capital. Vol.6 No. 3. pp.397-416.

3. Abidin. (2000). Efforts to Develop New Measures. Media Accounting. Edisi 7. Thn, VIII, pp. 46-47.

4. Ali Irfan. (2002). Financial Reporting and Information Asymmetry in Agency Relationships. Economic Trajectory. Vol.XIX No.2 Juli 2002.

5. Asma 'a Al-Amarneh. (2012). Corporate Governance, Ownership Structure and Bank Performance on Profitability and Bank Operational Efficiency. Journal 2012.

6. Bontis,N, (1998). Intellectual Capital: An Exploratory study that Develops Measures and Models. Management Decision .Vo;.36No.2.pp 63-76 
7. Bontis, N. and Keow,W.C.Richardson,S. (2000). Intellectual capital And Business Performance in Malaysian Industries. Journal of Intellectual Capital, vol.1.2000,pp.85-100.

8. Bauer, Rob, Nadja, and Roger. (2003). Empirical Evidance on Corporate Governance In Europe; The Effect on Stock Return, Firm Value and Performance.

9. Bambang Sudiyatno. (2010). Analysis of the Influence of Third Party Funds, BOPO, CAR and LDR on Financial Performance in the Banking Sector Go Public in the Indonesia Stock Exchange (IDX) period 2005-2008.

10. Bornemann and Leitner. (2002). Measuring and Reporting Intellectual Capital ; The Case of a. Research Technology Organization.Singapore Management Review Vol.24 No.3 pp 7-19

11. Brennan, N. (1999) Reporting and Managing In tellectual Capital; Evidence from Ireland. Paper presented at the International Symposium Measuring and Reporting Intellectual capital ;Experiences,Issues and Prospects, June, Amsterdam.

12. Budiadriani (2014), The Influence of Intellectual Capital Components and Corporate Governance Mechanisms on Financial Performance and Value of Companies Listed on Indonesia Stock Exchange, Dissertation

13. Chen, M,Cheng, S. \& Hwang. Y. (2005). An Empirical Investigation of the Relationship Between Intellectual capital and Firms' Market Value and Financial Performance, Journal of Intellectual Capital, 6 (2). 159-176.

14. Daniel Zeghal and Anis Maaloul, (2010). Analysing Value Added as an Indicator of Intellectual capital and its Consequences on Company Performance Journal of Intellectual Capital. Vol.11 No.1, 2010,39-60.

15. Edvinsoon. L, and Sullivan, P, (1996). Developing Model For Managing Intellectual Capital. European Management Journal, Vol.14 No.4, 356-364.

16. Farah Margaretha and, Arief Rakhman, (2006), Analysis of the Influence of Intellectual Capital on Market Value and Financial Performance of Companies With Value Added Methods Intelectual Coefficient Journal of Business and Accounting, Vol. 8, No. 2, August 2006, 199-217.

17. Fier, S. and Williams, SM (2003). Intellectual capital and traditional Measures of corporate performance, Journal of Intellectual Capital, Vol 4. No.3 pp 348-360.

18. Gary Stanley Becker. (1962). Investment in Human Capital : A Theoretical Analysis, The Journal of Political Economy, Volume 70, Issue 5, Part 2, Oct, 1962, 1-48

19. Gusti Bagus Angga Pratama and I Gusti Bagus Wiksuana. (2016). Effect of Firm Size and Leverage on Firm Value with Profitability As a Mediating Variable

20. Harmono (2014) Balanced Scorecard Based Financial Management Approach Theory, Case, and Business Research, Publisher Bumi Aksara. Jakarta.

21. Harrison, S, and P.H. Sullivan (2000), Profitting Form Intellectual capital; Learning from leading companies, journal of intellectual capital Vol 1. No. 1, 33-46.

22. Leila Asadi (2012). Investigating The Effect of Intellectual capital on The Value Creation of Companies Listed in Tehran Stock Exahange, Science Road Publishing Corporation, Trends in Social Science, 2(1). 2-12. 
23. Mei Fen Wu, Yu Je Lee, and Goa Liang Wang. (2012). To Verify How Intellectual capital Affects Organizational Performance in Listed Taiwan IC Design Companies With Considering the Moderator of Corporate Govermance. The Journal of Global Business Management, volume 8, Number 1, February 2012, 20-32.

24. Ming Chin Chen, Shu Ju Cheng, and Yuhchang Hwang, (2005). An Empirical Investigation of the Relationship Between Intellectual capital and Firms Market Value and Financial Performance Journal of Intellectual Capital. Vol,6,No.2,2005,159-176.

25. Mu Shun Wang. (2011). Intellectual capital and Firm Performance Annual Conference on Innovations in Business \& management London, UK, 2011, 1-26.

26. Nora Riyanti Ningrum, and Shiddig Nur Rahardjo, (2012) Analysis of the Influence of Intellectual Capital and Corporate Governance on Financial Performance. Diponegoro Journal of Accounting, Volume 1, Nomor 2, Tahun 2012, 1-15

27. Nova Lili Entika, dan Didik Ardiyanto, (2012). Intellectual Capital Formation Elements on Market Value and Financial Performance in Banking Companies listed on the Indonesia Stock Exchange, Diponegoro Journal of Accounting, Volume 1, Nomor 2, tahun 2012, 1-11

28. Olayinka Marte Uadiale, and Uwalomwa Uwugbe, (2011). Intellectual capital and Business Performance; Evidence from Nigeria Interdisciplinary Journal of Research in Business, Volume 1. Issue 10 November 2011, 49-56.

29. Omid Amri, and Mohamadreza Abdoli, (2012). The Relationship Between Intellectual capital and Performance of Companies (A Case Study of Cement Companies Listed in Tehran Stock Exchange). World Applied Sciences Journal 20 (4).520-526.

30. Rasyid, A. (2015). Influence of Ownership Structure, Company Size and Profitability on Dividend Policy and Value of Manufacturing Company in BEI. Dissertation.

31. Rifai, M., Arifati, R., dan Magdalena, M. (2014). The effect of Firm Size, Capital Structure, and Corporate Growth on Profitability Study at Manufacturing Company in BEI. Journal of Accounting University Panadaran.

32. Riahi-Belkaolu, A. (2003). Intellectual capital and Firm Performance of US Multinational Firm's astudy of the Resource-based and Stakeholder Views. Journal of Intellectual capital Vol. 4. No.2 , 215-226.

33. Sawarjuwono, T, (2003). Intellectual capital ; Treatment, Measurement, and Reporting (a Library Research), Journal of Accounting and Finance, Vol, 5 No,.1, 35-57.

34. Seyed Alireza Mosavi, Shekoufeh Nekoueizadeh, and Mahnoosh Ghaedi, (2012). A Study of Relations Between Intellectual capital Components, Market Value and Finance Performance African Journal of Business Management, Vol. 6 (\$), 1 February 2012, 1396-1403.

35. Sullivan Jr, P.H. and P.H. Sullivan Sr. (2000). Valuing Intangible Companies, Anintellectual capital Approach. Journal of Intellectual capital Vol. 1 No.4, 328-340.

36. Sulaeman Rahman Nidar (2015), Modern Corporate Finance Management, publisher Pustaka Reka Cipta, Bandung. West Java 40423

37. Tan. H.P.D. Plowman, and P. Hancock. (2007), Intellectual capital and Financial return of companies, Journal of Intellectual capital Vol,8. No.1. 76-95. 
38. Theodore Willian Schultz, (1961). Invesment in Human Capital. The American Economic Review, Vol. 15. No.,1, Maret 1961, 1-17.

39. Triyuwono, (2006), Sharia Accounting, Perspectives, Methodology, and Theory, Jakarta; PT. Raja Grafindo Persada.

40. Wasimul Rehman, Hafeez ur Rehman, Muhammad Usman, and Nabila Asghar, (2012). A Link Of Intellectual capital Performance With Corporate Performance: Comparative Study From Banking Sektor In Pakistan, International Journal of Business and Social Science Vol.3 No. 12 (Special Issue- June 2012). 